\title{
Qual "Fortalecimento" da Agricultura Familiar? Uma análise do Pronaf crédito de custeio e investimento no Rio Grande do Sul
}

\author{
Marcio Gazolla' e Sergio Schneider ${ }^{2}$
}

Resumo: Este artigo tem o objetivo de estudar o Programa Nacional de Fortalecimento da Agricultura Familiar (Pronaf) nas suas linhas de crédito para custeio e investimento, com o intuito de investigar suas relações e interfaces com a agricultura familiar, utilizando-se de um estudo no Rio Grande do Sul (microrregião do Médio Alto Uruguai). A pergunta a ser respondia é: qual o tipo de fortalecimento que o Pronaf gera junto aos agricultores familiares? Para isso, se usa como base uma metodologia qualitativa, com a utilização de entrevistas semiestruturadas e se apoia nas argumentações com dados secundários de diversas fontes e pesquisas. Conclui-se que o Programa tem lógica dupla. De um lado, ele está financiando as atividades de produção habituais dos agricultores, como grãos e commodities agrícolas. De outro, há um processo de diversificação econômica das atividades produtivas, das pequenas criações, cultivos e de alimentos básicos ao consumo das famílias.

Palavras-chaves: Pronaf, crédito rural, agricultura familiar, desenvolvimento rural.

Abstract: This article aims to study the National Programme for Strengthening Family Agriculture (Pronaf) in their credit lines for costing and investment, in order to investigate their relationships and interfaces with the family farm, using it for a study in Rio Grande do Sul (Middle High Uruguay microregion). The question to be answered is: what kind of building that is generating Pronaf with family farmers? To do this, it was used a methodology based on qualitative, using semi-structured interviews and underpinned by arguments with secondary data from various sources and research. It is concluded that the program has a dual logic. On the one hand, it is financing production activities usual for farmers, such as grain and agricultural commodities. On the other hand, there is a process of economic diversification of productive activities, small livestock, crops and basic food for household consumption.

Key-words: Pronaf, rural credit, family farming, rural development.

Classificação JEL: Q, Q1, Q18.

1 Engenheiro agrônomo, mestre e doutor em Desenvolvimento Rural. Professor da Universidade Federal de Santa Maria (UFSM/CAFW).E-mail: marciogazolla@smail.ufsm.br

2 Sociólogo, mestre e doutor em Sociologia. Professor da Universidade Federal do Rio Grande do Sul (UFRGS), nos programas de pós-graduação em Sociologia (PPGS) e Desenvolvimento Rural (PGDR). E-mail: schneide@ufrgs.br 


\section{Introdução}

O surgimento do Pronaf é um marco na intervenção do Estado na agricultura brasileira, porque representa a incorporação efetiva dos agricultores familiares às políticas para o meio rural. Em 2004, Schneider et al. afirmaram que "[...] o surgimento do Pronaf representa o reconhecimento e a legitimação do Estado em relação às especificidades de uma nova categoria social - os agricultores familiares - que até então era designada por termos como pequenos produtores, produtores familiares, produtores de baixa renda ou agricultura de subsistência" (2004, p. 21).

O Pronaf emerge na década de 1990 como a principal política de apoio econômico e produtivo à agricultura familiar, a partir da qual outras políticas e programas importantes foram desenhados, visando integrar as ações governamentais para este segmento social. Pode-se citar, por exemplo, o Programa de Aquisição de Alimentos (PAA), a Lei da Agricultura Familiar, o Seguro Rural, a nova Assistência Técnica e Extensão Rural (Ater) e, mais recentemente, o Programa Nacional de Alimentação Escolar (PNAE), que já existia desde os anos 1950, mas foi reestruturado visando atender a compra de alimentos dos agricultores ${ }^{3}$.

3 Nos anos recentes, observa-se um número crescente de avaliações e estudos sobre o Pronaf, principalmente nos últimos anos do programa. Não se retomam os principais argumentos e resultados dos estudos, e não há uma seção de revisão do "estado da arte" em termos de análises do Pronaf. Deixamos apenas indicados os principais autores e respectivas análises que se consideram importantes ao debate: Planaf (1995), MAA (1996 e 1999), Carneiro (1997),
Neste artigo analisam-se as interfaces do Programa com os agricultores familiares beneficiados, tomando-se os dados dos recursos do crédito de custeio e investimento aplicados no Rio Grande do Sul, especialmente na região do Médio Alto Uruguai, local em que foi desenvolvida a pesquisa empírica. Nosso objetivo consiste em investigar quais os tipos de fortalecimentos que o Programa tem desenvolvido junto aos agricultores familiares, analisando, para isso, principalmente as diferentes atividades produtivas e econômicas apoiadas pelo Pronaf.

A indagação central que este artigo busca responder refere-se ao tipo e à forma de fortalecimento que o Pronaf tem gerado na agricultura familiar desde seu surgimento. Para responder a essa questão, em torno da qual se estruturam os argumentos do texto, analisa-se o Pronaf a partir de lógicas de ação diferenciadas. De um lado, sustenta-se que o Programa fortaleceu a inserção produtiva histórica da agricultura familiar, como ocorre nos casos do fomento à produção de grãos e commodities agrícolas, com destaque aos cultivos do milho e da soja. Nesse tipo de desenvolvimento nota-se um aumento dos processos de especialização produtiva das unidades, da vulnerabilidade social das famílias e processos crescentes de mercantilização social e econômica (aumento da compra de insumos e

Abramovay e Veiga (1999), Pereira Silva e Alves Filho (2009), Ibase (1999), Schneider et al. (2004), Ferreira e Gaiger (2004), Gazolla e Schneider (2005), Mattei (2006, 2007), Abramovay e Magalhães (2007), Guanziroli (2007), Souza et al. (2010), Aquino e Schneider (2010), Aquino et al. (2011), Souza et al. (2011). 
tecnologias externas). Procura-se demonstrar que esta dinâmica é mais saliente do que a segunda apresentada no trabalho.

Por outro lado, no entanto, o Pronaf estimula a produção própria de pequenos alimentos/ criações dos agricultores e a diversificação rural. Esta produção para o autoconsumo é voltada ao trato dos animais e à produção de alimentos que servem a própria segurança alimentar e nutricional do grupo doméstico. Contudo, esse fortalecimento que o Programa proporciona, em geral, é periférico e indireto sobre as unidades familiares, pois recebe menos recursos e fomento menor do que o anterior. Neste sentido, o Pronaf está imerso em uma ambiguidade, pois ao mesmo tempo em que é um Programa que apoia e estimula os agricultores familiares a intensificarem seus sistemas produtivos, também incita as famílias a buscarem alternativas a este tipo de desenvolvimento ${ }^{4}$.

A importância do Pronaf também pode ser avaliada pelos recursos alocados para a agricultura familiar, bem como sobre o numero de contratos firmados. Segundo dados do MDA (2010), os recursos para custeio e investimento do Programa têm crescido constantemente, o que demostra a tendência de o mesmo seguir apoiando as ações econômicas e produtivas dos agricultores. Por exemplo, para o Brasil, no período de 2003 a 2010, os recursos cresceram de 2,4 bilhões para 16 bilhões, o número de contratos, de 890 mil para 2 milhões por ano, e os valores médios por contrato, de $\mathrm{R} \$ 2.400,00$ para R\$ 7.478,00. Só no Plano Safra 2011/12 se tem a

4 Ressalta-se que se considera o Pronaf uma política extremamente importante ao desenvolvimento rural brasileiro, especialmente por ser a principal no apoio econômico e produtivo da agricultura familiar e por ter de um volume grande de recursos, principalmente nos últimos Planos Safras. Reconhecem-se os seus méritos, bem como os seus efeitos benéficos sobre os espaços rurais do País; no entanto, isso não nos isenta de apontar alguns gargalos e aspectos que podem ser melhorados para que o Programa efetivamente avance na sua trajetória de mudanças e evoluções, principalmente quando se analisa o Programa na região em investigação e no RS. Desse modo, algumas críticas feitas ao Pronaf nesse trabalho são no intuito de aprimorar sua importância junto aos agricultores, seus movimentos sociais e o próprio Estado brasileiro. projeção de investir em torno de 15 bilhões para as ações de custeio e investimento e, para o Plano Safra 2012/2013, em torno de 18 bilhões.

Parte expressiva destes recursos públicos foi aplicada no Sul do País (RS, SC e PR), pois esta região acessa grande fatia dos recursos desde o nascimento da política. Por exemplo, em 1996, a região acessou 78,6\% dos recursos do Programa. Em 2000, foram 50,7\% dos recursos. Entre 2003 e 2008, a região acessou $44 \%$ do total de recursos disponibilizados. Esta região saiu do patamar de 486.585 mil contratos em 1999 para 631.281 mil em 2007. Também os valores aplicados são representativos, evoluindo de $\mathrm{R} \$ 1.569,00$ milhões para R \$ 4.061,7 milhões no mesmo período. Conforme dados do MDA (2010), em 2009, só o RS efetuou mais de 700 mil contratos e recebeu mais de $\mathrm{R} \$ 5$ bilhões do Programa. Estes dados demonstram que percentuais importantes dos recursos são tomados pela região Sul do País e pelo RS se comparados à totalidade do Brasil.

Segundo o IBGE (2006), na região Sul do País a agricultura familiar é predominante, com 849.997 estabelecimentos e área de 13.066.591 ha. Essa região também tem o segundo maior contingente de agricultores familiares que acessam o Pronaf, com 19,17\%, atrás apenas da região Nordeste, que possui $50,82 \%$. Sozinho, o RS tem 378.546 estabelecimentos familiares em uma área de 6.171.622 ha. Tanto os dados dos recursos aplicados pelo programa na região Sul quanto os da predominância da agricultura familiar justificam a realização de investigações sobre o Pronaf, no sentido de verificar quais os seus efeitos sobre as atividades econômicas e produtivas no meio rural, bem como junto ao público beneficiário.

Quanto aos procedimentos metodológicos, embora se usem alguns dados quantitativos derivados de outras investigações para caracterizar o programa no RS, a análise desenvolvida se centra principalmente no uso de uma metodologia qualitativa, através da utilização de entrevistas semidiretivas com agricultores familiares, as suas organizações de representação política 
e instituições de desenvolvimento rural 5 . As entrevistas foram realizadas em seis municípios do Médio Alto Uruguai (RS) (porção do extremo norte): Constantina, Frederico Westphalen, Taquaruçu do Sul, Três Palmeiras, Palmitinho e Vista Alegre, todos pertencentes à microrregião de Frederico Westphalen, tal como definida pelo IBGE.

Nas entrevistas se pretendeu abranger uma gama variada de instituições e atores sociais ligados ao desenvolvimento da região, propiciando a coleta de dados e informações heterogêneas e diversificadas dos entrevistados. Nestas entrevistas, os principais dados levantados consideraram: entender a lógica mais geral de funcionamento do Pronaf no local; verificar quais os principais empreendimentos econômicos e produtivos o programa estava financiando; entender a dinâmica dos empreendimentos apoiados voltados aos grãos e commodities; analisar quais modalidades do Pronaf estavam presentes nas dinâmicas das famílias; verificar como o Pronaf fomentava as pequenas produções/ criações, a diversificação rural, a produção para o autoconsumo e a segurança alimentar das famílias.

O artigo está dividido em quatro seções principais, além da introdução e das considerações finais. $\mathrm{Na}$ primeira, apresenta-se uma contextualização geral da região do Médio Alto Uruguai e da sua história agropecuária. Na segunda, discute-se brevemente a evolução do programa, com base em quatro momentos

\footnotetext{
5 Para a obtenção das informações qualitativas foram realizadas 23 entrevistas semiestruturadas com 26 atores sociais. Foram entrevistados oito agricultores familiares, quatro secretários municipais da agricultura (SAM), seis técnicos, agrônomos e extensionistas rurais da Emater, dois representantes de Conselhos Municipais de Desenvolvimento Rural (CMDRs), o presidente do Conselho de Desenvolvimento do Médio-Alto Uruguai (Codemau) e organizações sociais e de representação política dos agricultores familiares, sendo um representante da Cooperativa de Produção Agropecuária Constantina - Ltda (Coopac), um da Federação dos Trabalhadores na Agricultura do Rio Grande do Sul (Fetag - Coordenador Regional), dois da Federação dos Trabalhadores na Agricultura Familiar do Sul do País (Fetraf-Sul) e um membro do Movimento dos Pequenos Agricultores (MPA).
}

históricos considerados diferenciados quanto aos acontecimentos centrais que estruturaram o Pronaf. Na terceira, analisam-se alguns dados do crédito rural do programa no RS e algumas das atividades produtivas e econômicas ligadas à produção de grãos e commodities que o mesmo está financiando. Na quarta seção, aborda-se a maneira como o programa atua na diversificação agrícola, na produção de alimentos básicos, nos pequenos cultivos/criações e alimentos para o consumo dos agricultores.

\section{A região do Médio Alto Uruguai (RS) em que a agricultura familiar está imersa}

O Médio Alto Uruguai do RS é tipicamente um local de colonização por imigrantes de ascendência europeia, principalmente italianos, alemães e poloneses. A colonização é recente, se comparado às demais do RS, pois estas colônias "novas" foram constituídas a partir de 1925, com a instalação da Comissão de Terras pelo governo estadual, na cidade de Palmeiras das Missões. Esta característica fez com que o norte gaúcho desenvolvesse, historicamente, sistemas produtivos com a predominância da forma social familiar de produção, trabalho e ocupação dos seus espaços rurais.

Os dados do censo agropecuário do IBGE de 2006 ajudam a revelar a importância dessa agricultura de base familiar no local. Segundo o IBGE (2006), a microrregião de Frederico Westphalen tem 23.090 estabelecimentos agropecuários, sendo que os familiares atingem $93,04 \%$ do total. Com relação à área, é de 288.114 ha, que é igual a 73,97\% da área de terras da microrregião. Quando se analisa o pessoal ocupado na agropecuária, encontram-se 64.801 pessoas, das quais $91,86 \%$ são familiares. A média de tamanho das propriedades rurais não chega a 13 hectares (12,47 ha). Segundo o Conselho de Desenvolvimento Territorial (CODETER, 2010) a população total da região é de 193.402 habitantes, dos quais 102.168 vivem na área rural $(52,83 \%$ 
do total), sendo uma região classificada como predominantemente rural. No conjunto, a região tem, ainda, 26.429 agricultores familiares, 109 famílias assentadas e seis áreas demarcadas como terras indígenas.

Alguns dados estatísticos auxiliam a entender o contexto mais geral do local, como os fornecidos pela Fundação de Economia e Estatística (FEE, 2011) para o Conselho de Desenvolvimento do Médio Alto Uruguai (Corede), que podem ser visualizados no Quadro 1. O Corede tem população total de 152.501 mil habitantes, área de $4.337,5 \mathrm{~km}^{2}$, densidade demográfica de $35,2 \mathrm{hab} /$ $\mathrm{km}^{2}$, taxa de analfabetismo de $9,42 \%$, expectativa de vida ao nascer de 71,25 anos, coeficiente de mortalidade infantil de 7,85 por mil nascidos vivos, PIB/por município de $\mathrm{R} \$ 1.847 .711,00$, PIB per capita de $\mathrm{R} \$ 11.629,00$ e exportações totais de U\$ FOB 38.635.934,00.

O desenvolvimento da agricultura regional passou por várias fases diferentes. Fazendo-se uma breve periodização, pode-se dizer que houve quatro fases: (a) uma de colonização, desbravamento das matas e constituição das primeiras atividades agropecuárias desenvolvidas quase que exclusivamente visando a sobrevivência e o autoconsumo das famílias. Esse estágio abrange o inicio do século XX e se detém à produção básica de gêneros alimentícios como batata, mandioca, feijão, arroz, suínos e banha; (b) uma segunda fase, que compreende a maior integração aos mercados e o início do processo de especialização produtiva. Essa fase engloba o período de 1935 a 1960 e se caracteriza pelo início do avanço das lavouras de milho, soja, trigo e também de erva mate.

A terceira fase (c) compreende o período de 1960 ao início dos anos 90, caracterizada pela intensa mercantilização da agricultura e seu contínuo empobrecimento econômico e social (CONTERATO et al., 2007). Isso é derivado do avanço dos processos de modernização agrícola, que fomentou grandemente cultivos como a soja, milho, fumo e outros grãos e commodities, além de processos de integração vertical em cadeias de aves e suínos; (d) a partir dos anos 1990, se observa um pequeno movimento da diversificação da economia rural, onde surgem atividades novas como a fruticultura, o leite, as agroindústrias familiares, entre outras atividades em pequena escala. As atividades rurais não agrícolas e a pluriatividade são muito pequenas no local, sendo uma região predominantemente agropecuária.

Essas formas de desenvolvimento microrregional levaram a fragilidades históricas, sociais e econômicas. Estas podem ser notadas quando se analisam dados estatísticos, como o Índice de Desenvolvimento Socioeconômico (Idese), da FEE (2011), para os Coredes do RS, no ano de 2008. O Corede do Médio Alto Uruguai é o de menor Idese, estando em última colocação em termo estaduais, com 0,685 , bem atrás do estado do RS $(0,772)$ e dos dois primeiros Coredes do estado, Corede Serra $(0,815)$ e Corede Metropolitano do Delta do Jacuí $(0,810)$. Segundo o Codeter $(2010)$

Quadro 1. Alguns indicadores do Corede do Médio Alto Uruguai (RS)

\begin{tabular}{lc}
\hline \multicolumn{1}{c}{$\begin{array}{c}\text { Alguns indicadores do Corede do } \\
\text { Médio Alto Uruguai }\end{array}$} & Números/indicadores \\
\hline População total (em mil habitantes) & 152.501 \\
Área total $\left(\mathrm{km}^{2}\right)$ & $4.337,50$ \\
Taxa de analfabetismo (\%) & 9,42 \\
Expectativa de vida (anos) & 71,25 \\
Coeficiente de mortalidade infantil (por mil nascidos) & 7,85 \\
PIB por município (R\$) & $1.847 .711,00$ \\
PIB per capita (R\$) & $11.629,00$ \\
Exportações totais (U\$S FOB) & $38.635 .934,00$ \\
\hline
\end{tabular}

Fonte: FEE (2011). 
o Índice de Desenvolvimento Humano (IDH) do local também é baixo quando comparado ao estadual, já que o regional é de 0,760 e o do RS, 0,814, em 2000. Essas vulnerabilidades socioeconômicas estão principalmente nos espaços rurais, visto que a maior parte da população regional ainda reside neles, sendo principalmente agricultores familiares, como os dados apresentados anteriormente evidenciam.

\section{Um breve histórico do Pronaf}

O Pronaf passou por muitas modificações durante a sua evolução, e algumas das mais importantes e recentes são discutidas na presente seção. O Programa começou em 1995/96, com quatro áreas de atuação básicas: no financiamento do custeio e investimento agrícolas; fornecimento de infraestrutura rural; negociação e articulação de políticas públicas e formação de técnicos extensionistas e agricultores. Nesse momento inicial do programa, as taxas de juros eram altas (12\% a.a.) e houve pouco acesso dos agricultores, principalmente em função do desconhecimento da politica pelos mesmos e suas organizações, com exceção da região Sul, que, devido ao fato de agricultores serem mais inseridos nas dinâmicas dos mercados, se sobressaiu (ABRAMOVAY e VEIGA, 1999).

Num segundo momento, que se inicia em 1999, o Pronaf começa um movimento de redução das taxas de juros. Também ocorreu a incorporação do público assentado da reforma agrária ao Programa, devido à extinção do Programa de Crédito Especial para a Reforma Agrária (Procera). Com a incorporação deste público aos demais agricultores familiares, o Pronaf divide-se em grupos: "A", "B", “C" e "D", tomando como base o critério da renda bruta anual familiar (BRANCOLINA e GAIGER, 2004). Nesse período, o volume total de recursos não cresce tanto, embora o número de contratos aumente em função do maior número de agricultores que passam a acessar o programa.
Num terceiro momento, que vai mais ou menos de 2003 a 2008, há novas reduções das taxas de juros e a principal medida é a diversificação das linhas de financiamento do programa, incluindo muitas atividades do debate sobre o "novo rural brasileiro" e outros públicos-alvo. São dessa fase a criação do Pronaf Agregar, Mulher, Agroecologia, Turismo Rural, Jovem Rural, Alimentos, entre outras modalidades. Nessa fase os grupos do Pronaf têm as faixas de renda bruta anuais alargadas e os grupos " $\mathrm{C}$ " $\mathrm{e}$ " $\mathrm{D}$ " tomam a frente dos financiamentos do programa, retendo a maior parte dos recursos em regióes e agricultores mais capitalizados (AQUINO e SCHNEIDER, 2010; SOUZA et al., 2011). Também nesse período os volumes de crédito disponibilizados são crescentes anualmente.

Nos últimos anos, o programa continua reduzindo os juros sobre os financiamentos, ampliando os volumes de recursos disponibilizados e tentando articular o Pronaf com outras politicas, como o Programa de Aquisição de Alimentos (PAA), a Assistência Técnica e Extensão Rural (nova Lei de Ater) e o Seguro Rural, entre outras. Contudo, a mudança mais expressiva foi a extinção dos grupos antigos do Programa e a criação de novos grupos (microcrédito rural, custeio e investimento para a agricultura familiar e as demais modalidades citadas anteriormente, com pequenas modificações), com a existência de faixas de valores de acesso aos recursos e juros específicos por faixa (PLANO SAFRA, 2009/2010 e 2010/ 2011).

Conforme a Tabela 1, o Programa, entre 1999 e 2010, disponibilizou R $\$$ 87.026.000.000,00 aos agricultores brasileiros. Destes recursos, foram efetivamente aplicados R \$ 66.245.696.579,55, uma diferença entre o disponibilizado e o aplicado de R\$ 20.780.303.420,45, que corresponde a $76,12 \%$ de todos os recursos disponibilizados. Os recursos e o número de contratos também evoluíram, passando de R\$2.149.434.466,14 em recursos aplicados e 926.422 contratos, em 1999, para $\mathrm{R} \$ 10.626 .236 .252,00$ e 1.366 .325 contratos, em 2010. Estes números demonstram a intenção 
Tabela 1. Brasil - Número de contratos e montantes de recursos disponibilizados e aplicados pelo Pronaf, entre 1999 e 2010

\begin{tabular}{|c|c|c|c|c|c|}
\hline \multirow{2}{*}{ Ano-safra } & Disponibilizado & Aplicado & \multirow{2}{*}{ Diferença } & \multirow{2}{*}{$\%$ Aplicado } & \multirow{2}{*}{ Contratos } \\
\hline & (R\$) & (R\$) & & & \\
\hline $1999 / 2000$ & 3.280 .000 .000 & $2.149 .434 .466,14$ & $1.130 .565 .533,86$ & 65,53 & 926.422 \\
\hline $2000 / 2001$ & 3.976 .000 .000 & $2.168 .486 .228,50$ & $1.807 .513 .771,50$ & 54,54 & 893.112 \\
\hline $2001 / 2002$ & 4.196 .000 .000 & $2.189 .275 .083,64$ & $2.006 .724 .916,36$ & 52,18 & 932.927 \\
\hline $2002 / 2003$ & 4.174 .000 .000 & $2.376 .465 .864,08$ & $1.797 .534 .135,92$ & 56,93 & 904.214 \\
\hline $2003 / 2004$ & 5.400 .000 .000 & $4.490 .478 .228,85$ & $909.521 .771,15$ & 83,16 & 1.309 .168 \\
\hline $2004 / 2005$ & 7.000 .000 .000 & $6.131 .600 .933,40$ & $868.399 .066,60$ & 87,59 & 1.635 .051 \\
\hline $2005 / 2006$ & 9.000 .000 .000 & 7.611.929.143,94 & $1.388 .070 .856,06$ & 84,58 & 1.913 .043 \\
\hline $2006 / 2007$ & 10.000.000.000 & $8.434 .174 .742,00$ & $1.565 .825 .258,00$ & 84,34 & 1.692 .516 \\
\hline $2007 / 2008$ & 12.000 .000 .000 & $9.082 .136 .305,00$ & $2.917 .863 .695,00$ & 75,68 & 1.650 .622 \\
\hline $2008 / 2009$ & 13.000 .000 .000 & $10.985 .479 .332,00$ & $2.014 .520 .668,00$ & 84,5 & 1.443 .217 \\
\hline $2009 / 2010$ & 15.000.000.000 & $10.626 .236 .252,00$ & $4.373 .763 .748,00$ & 70,84 & 1.366 .325 \\
\hline Total & 87.026 .000 .000 & $66.245 .696 .579,55$ & $20.780 .303 .420,45$ & 76,12 & 14.666 .617 \\
\hline
\end{tabular}

Fonte: Coppeti (2008) e MDA/SAF (2010).

Tabela 2. Rio Grande do Sul - Número de contratos e valores aplicados pelo Pronaf, entre 1998 e 2010

\begin{tabular}{cccc}
\hline Ano & $\mathbf{N}^{\circ}$ De Contratos & Montante $\mathbf{( R \$ )}$ & Valor Unitário $\mathbf{( R \mathbf { } )}$ \\
\hline $1998 / 1999$ & 42.487 & $95.695 .802,03$ & $2.252,35$ \\
$1999 / 2000$ & 310.592 & $544.584 .618,33$ & $1.753,38$ \\
$2000 / 2001$ & 285.169 & $547.624 .808,11$ & $1.920,35$ \\
$2001 / 2002$ & 270.593 & $600.963 .626,93$ & $2.220,91$ \\
$2002 / 2003$ & 252.886 & $650.599 .888,46$ & $2.572,70$ \\
$2003 / 2004$ & 270.037 & $949.608 .194,87$ & $3.516,59$ \\
$2004 / 2005$ & 354.078 & $1.350 .093 .569,59$ & $3.812,98$ \\
$2005 / 2006$ & 343.680 & $1.399 .822 .482,13$ & $4.073,04$ \\
$2006 / 2007$ & 287.302 & $1.442 .733 .588,16$ & $5.021,66$ \\
$2007 / 2008$ & 337.533 & $2.063 .365 .754,83$ & $6.113,08$ \\
$2008 / 2009$ & 858.215 & $2.974 .057 .535,00$ & $3.465,40$ \\
$2009 / 2010$ & 375.648 & $2.746 .867 .008,00$ & $7.312,34$ \\
Total & 3.988 .220 & $\mathbf{1 5 . 3 6 6 . 0 1 6 . 8 7 6}$ & $3.852,85$ \\
\hline
\end{tabular}

Fonte: Coppeti (2008) e MDA/SAF (2010).

do Programa de seguir apoiando com crédito rural as atividades produtivas e econômicas dos agricultores. Somente nos últimos planos safras, a partir do de 2008/2009, se notam pequenas diminuições nos valores aplicados e no número de contratos.

A Tabela 2 traz essa mesma evolução do Programa para o Rio Grande do Sul. De 1998 a 2010, R\$ 15.366.016.876 foram aplicados no estado e 3.988.220 contratos foram firmados, com valor médio de $\mathrm{R} \$ 3.852,85$ por contrato. Também se observa a tendência de o Pronaf evoluir no sentido de alocar recursos crescentes aos agricultores a cada Plano Safra, com exceção do 2009/2010, em que houve uma pequena queda no número de contratos e nos montantes aplicados. Contudo, os valores médios dos contratos são crescentes a cada Plano Safra. O RS sai de um patamar de aplicação de recursos de $\mathrm{R} \$$ 95.695.802,03 com a celebração de 42.487 contratos, em 1998, para cifras de $\mathrm{R} \$ 2.746 .867 .008,00$ e 375.648 contratos em 2010. 
Na seção seguinte se investigam as atividades produtivas e econômicas que o Pronaf está financiando junto aos agricultores da região do Médio Alto Uruguai (RS), discutindo-se as ações de fortalecimento junto à agricultura familiar local.

\section{Pronaf: Uma evolução com melhorias ou "fazendo mais do mesmo"?}

$\mathrm{Na}$ presente seção, evidencia-se o tipo de fortalecimento que o Pronaf gera na agricultura familiar, tomando-se por base os principais pressupostos sobre os quais o Programa foi formulado inicialmente pelo Estado, bem como por meio dos dados estatísticos dos tipos de financiamentos e da pesquisa empírica qualitativa na região do Médio Alto Uruguai (RS). Retomando as questões já levantadas na introdução, o que se coloca como perguntas são: (a) Qual o tipo de fortalecimento que o Pronaf está gerando junto à agricultura familiar local? (b) Será que o tipo de fortalecimento que o Programa está apoiando, em partes, não tem ajudado a fragilizar a agricultura? São estas perguntas que se tenta responder nestas duas próximas seções.

O tipo de fortalecimento que o Pronaf gera na agricultura familiar pode ser analisado com base nas suas modalidades de crédito e na análise das atividades produtivas e econômicas que o Programa financia junto aos agricultores. Ebina e Massuquetti (2010), estudando o programa no RS, no período de 1999 a 2008, têm alguns dados interessantes. No Brasil, o Programa destina os recursos da seguinte forma: no custeio agrícola, 99,93\% dos recursos ficam para a aplicação em lavouras. No custeio pecuário, 97,83\% são alocados para animais. No investimento agrícola, mais da metade dos recursos se concentra na rubrica máquinas e equipamentos (52,70\%). Já no investimento pecuário, $57,70 \%$ dos recursos vão para a aquisição de animais.

Quando se analisam os dados por regióes do Brasil e pelo tipo de destinação dos recursos, nota-se que o Sul (RS, SC e PR) é privilegiado frente aos demais, pois tem, segundo dados do censo agropecuário do IBGE (2006), 849.997 mil estabelecimentos agropecuários, recebendo o total de recursos financeiros de $\mathrm{R} \$ 2.431 .837 .761,66$, e com valor médio por contrato de $\mathrm{R} \$ 2.861,00^{6}$. Na regiãoSul, os dados do Programa parecem apontar para uma concentração e certo direcionamento dos recursos para algumas atividades em detrimento de outras. Por exemplo, os recursos do custeio agrícola são voltados principalmente para culturas como milho $(45,53 \%)$ e soja $(30,18 \%)$.

Em percentuais menores, os recursos são utilizados para outras destinações como: outras lavouras (8,10\%), trigo (6,36\%), arroz $(4,10 \%)$ e feijão $(2,63 \%)$. Já a parte de investimento agrícola concentra-se em duas aplicações principais: $69,4 \%$ destinam-se a máquinas e equipamentos e 16,25\%, em outras aplicações (EBINA e MASSUQUETTI, 2010). Estes dados evidenciam que, para o Sul do País, um padrão de destinação dos recursos em torno de lavouras habituais e de aquisição de máquinas e equipamentos agropecuários é prioridade principal do Programa ${ }^{7}$.

Este direcionamento do Programa pode ser visualizado na Tabela 3, que traz as principais atividades econômicas e produtivas financiadas, em ordem de importância, para os municípios pesquisados no Médio Alto Uruguai (RS). Verifica-se que a principal atividade financiada pelo crédito de custeio diz respeito à implantação

\footnotetext{
6 Valores superiores a, por exemplo, a região Nordeste, que tem mais que o dobro de estabelecimentos agropecuários (2.187.295), recebeu em 2006 o total de R\$ 637.717.278,96 e tem um valor médio por contrato muito mais baixo, em torno de R\$291,56, demonstrando as desigualdades na distribuição dos recursos. Para uma análise mais detalhada dessas desigualdades, consultar Aquino et al. (2011).

7 Para o resto do Brasil essa mesma tendência do Pronaf de financiar as culturas mercantis e de produção de grãos também é observada. Por exemplo, segundo dados do Bacen (2009) apud Ebina e Massuquetti (2010), o Programa volta seus recursos do crédito de custeio de lavouras para o milho $(36,25 \%)$, soja $(21,30 \%)$, outras lavouras $(13,17 \%)$ e café $(11,91 \%)$, dentre os cultivos mais financiados. Com estes dados, se observa uma lógica do Programa semelhante à da região Sul, que é de concentrar os recursos em poucos cultivos, pois se forem somados os percentuais aplicados em apenas duas culturas - milho e soja - tem-se quase $70 \%$ dos recursos aplicados $(67,55 \%)$.
} 
Tabela 3. Região do Médio Alto Uruguai - Principais atividades rurais financiadas pelo Pronaf Crédito de Custeio e Investimento, em ordem de importância

\begin{tabular}{|c|c|}
\hline Municípios & Principais atividades rurais financiadas \\
\hline Três Palmeiras & $\begin{array}{l}\text { - Custeio de lavouras de soja, milho, trigo e fumo (compra de insumos, sementes, adubos, fertilizantes). } \\
\text { - Bovinocultura de leite (formação de pastagens, aquisição de matrizes). } \\
\text { - Fruticultura (implantação de pomares de videiras). } \\
\text { - Melhoramento das propriedades físicas e químicas do solo (compra de calcário, distribuição de adubos } \\
\text { orgânicos, fertilizantes, adubação verde). }\end{array}$ \\
\hline Vista Alegre & $\begin{array}{l}\text { - Custeio de lavouras de milho, feijão e fumo (compra de insumos, sementes, fertilizantes, agrotóxicos). } \\
\text { - Bovinocultura de leite (aquisição de matrizes, medicamentos, ordenhadeiras, congeladores de } \\
\text { resfriamento). } \\
\text { - Melhoramento das propriedades físicas e químicas do solo (compra de calcário, fertilizantes, adubação } \\
\text { verde). } \\
\text { - Construção de infraestrutura rural (galpões de armazenamento de fumo e pequenos estábulos). }\end{array}$ \\
\hline Constantina & $\begin{array}{l}\text { - Custeio de lavouras das culturas de soja, trigo e milho (compra de insumos, fertilizantes e agrotóxicos). } \\
\text { - Bovinocultura de leite (aquisição de matrizes, ordenhadeiras, congeladores de resfriamento, tanques de } \\
\text { expansão, melhoramento de estábulos, compra de tanques de expansão e melhoramento de pastagens). } \\
\text { - Fruticultura (implantação de pomares de citros, pêssegos, videiras, nectarinas). } \\
\text { - Construção de agroindústrias familiares para agregação de valor à matéria-prima (compra de equipa- } \\
\text { mentos, materiais de trabalho, construção das instalações, aquisição de material de consumo permanente). }\end{array}$ \\
\hline Palmitinho & $\begin{array}{l}\text { - Custeio de lavouras de grãos como milho, soja, trigo, fumo etc. (aplicação dos recursos em fertilizantes, } \\
\text { agrotóxicos e insumos diversos). } \\
\text { - Bovinocultura de leite (aquisição de matrizes leiteiras, equipamentos de ordenha e de conservação do } \\
\text { leite, formação de pastagens, medicamentos, construção e melhoria de instalações). } \\
\text { - Correção das propriedades físicas e químicas do solo (compra de calcário, fertilizantes químicos, } \\
\text { adubação verde, controle de erosão, distribuição de adubos orgânicos). } \\
\text { - Aquisição de pequenas máquinas e equipamentos agrícolas (compra de motores estacionários, tritura- } \\
\text { dores, forrageiros, motosserras). } \\
\text { - Fruticultura (implantação de pomares de videiras, citros). }\end{array}$ \\
\hline $\begin{array}{l}\text { Frederico } \\
\text { Westphalen }\end{array}$ & $\begin{array}{l}\text { - Custeio de lavouras para as culturas de milho, soja, fumo e trigo (compras de fertilizantes químicos, } \\
\text { insumos diversos, sementes melhoradas e agrotóxicos). } \\
\text { - Bovinocultura de leite (aquisição de matrizes leiteiras, equipamentos de ordenha e conservação do leite, } \\
\text { melhoria de estábulos, melhoria e implantação de pastagens). } \\
\text { - Fruticultura (pomares de videiras, pêssegos, citros, figos). } \\
\text { - Suinocultura (construção e melhoria de pocilgas, construção de esterqueiras, compra de matrizes suínas, } \\
\text { compra de medicamentos e equipamentos). } \\
\text { - Criação de infraestrutura rural (construção e/ou melhoria de pequenos açudes, pocilgas, reforma de } \\
\text { galpões, manutenção e reforma de tratores). } \\
\text { - Financiamento de agroindústrias familiares para agregação de valor à matéria-prima (construção das } \\
\text { instalações, compra de máquinas e equipamentos, compra de material de consumo permanente). } \\
\text { - Piscicultura (construção de alguns açudes). }\end{array}$ \\
\hline Taquaruçu do Sul & $\begin{array}{l}\text { - Custeio de lavouras de milho, soja, fumo e trigo (financiamento dos insumos, fertilizantes químicos, } \\
\text { agrotóxicos e sementes melhoradas). } \\
\text { - Bovinocultura de leite (aquisição de matrizes, compra de equipamentos de ordenha e conservação, } \\
\text { melhoria de instalações). } \\
\text { - Fruticultura (implantação de pomares de citros, videiras). } \\
\text { - Infraestrutura rural (construção e/ou melhorias de instalações, galpões, pocilgas e estábulos). }\end{array}$ \\
\hline
\end{tabular}

Fonte: Pesquisa de campo (2004).

das lavouras de grãos e commodities agrícolas como a soja, o milho, o trigo, o fumo. Em apenas um caso analisado aparece o feijão. Estes resultados coincidem com os dados secundários antes apresentados para a região Sul do Brasil. Ressalta-se que, em estudos mais recentes, como o de Mattei (2006, 2007), em relação ao Brasil, e o de Toledo (2009), que estudou o Pronaf no
RS, estes produtos também aparecem como os principais financiados pelo Programa.

Como se sabe, estas lavouras são caracterizadas pelo uso intensivo de fertilizantes químicos, agrotóxicos, sementes melhoradas, máquinas agrícolas e até sementes geneticamente modificadas (no caso da soja), o que demonstra o tipo de agricultura que o Programa está 
apoiando. Estas lavouras também se utilizam de muitas tecnologias e insumos externos para serem viabilizadas, caracterizando o que Ploeg tem chamado de "externalização dos processos produtivos" (PLOEG, 2008).

É claro que, no caso das lavouras de milho, deve-se fazer uma ressalva, pois o milho é um cultivo que tem duplo papel nas unidades familiares. Ou seja, ele tem o que Garcia Jr. (1989) chamou de caráter da "alternatividade produtiva" ${ }^{\prime \prime}$. O milho pode ser tanto vendido aos diferentes mercados quanto consumido pelos animais ou pela família, dependendo das condições familiares e dos mercados. Além disso, na agricultura familiar, o milho tem vários usos na própria unidade de produção, como é o caso do uso na criação de pequenos animais como aves, cabras, ovelhas, suínos, entre outros (o chamado consumo intermediário). Dessa forma, quando o Pronaf financia a produção de milho, estará fornecendo uma commodity quando esta for para os mercados, ou fortalecendo o grupo familiar quando esse produto é utilizado pela família e no trato dos animais.

Desse modo, o Programa não tem ações que visam alterar estas atividades econômicas historicamente instituídas dos agricultores, o que, nesta região em investigação, é um dos motivos que os têm levado a um aumento de sua vulnerabilidade social (ELLIS, 2000). Este viés do Pronaf em continuar financiando o processo de mudança da base técnico-produtiva da agricultura já havia sido verificado por outros autores como Carneiro (1997, p. 71), que asseverou que o "padrão de organização da produção privilegiado pelo Pronaf sustenta-se nas noções de produtividade e na rentabilidade crescentes".

O privilegiamento das atividades produtivas rentáveis e os cultivos de maior inserção

8 Segundo as definições de Garcia Jr. (1989, p. 117): "Alternatividade entre (os produtos) serem consumidos diretamente e atender às necessidades domésticas de consumo e, serem vendidos, quando a renda monetária que proporcionam permite adquirir outros produtos também de consumo doméstico, mas que não podem ser produzidos pelo próprio grupo doméstico, como o sal, açúcar, querosene etc". mercantil do Pronaf são elucidados pelo relato de um agricultor familiar entrevistado. $\mathrm{O}$ agricultor formula que uma das contradições do Programa é a de que ele deveria financiar a produção de alimentos nas unidades, mas o que geralmente ocorre é ele apoiar o desenvolvimento da produção mercantil, pois "dá mais lucro".

Eu vejo assim, no meu entender, que o financiamento já é para gerar alimento para o produtor, só que, muitas vezes, o produtor não aplica nisso, muitas vezes, o produtor tem uma mentalidade, assim, que tem que aplicar naquilo que dá retorno [...]. Hoje o produtor prefere aplicar no que dá mais lucro, assim, mais para frente, que dá mais dinheiro, financeiramente (Entrevista 2, J. N., Agricultor familiar).

Outra questão é o pagamento do financiamento junto às instituições bancárias, o que gera pressões sobre as famílias. No momento em que o agricultor contrata um financiamento, a pergunta que ele se coloca é como vai realizar o pagamento? Isso o faz chegar à conclusão de que não se pode investir nas pequenas produções diversificadas de sua unidade, pois, se gastar os recursos do Programa nestas atividades, que não vão lhe gerar um excedente monetário em termos líquidos, como ele vai pagar o financiamento? O trecho da entrevista com um secretário municipal da Agricultura é explicativo desse processo.

É a própria lógica do financiamento que tem que ser discutida. No momento que o agricultor financia parece que ele tem que produzir para vender e pagar o financiamento e não para a sua subsistência. Vender alguma coisa para cumprir este teu contrato de pagar o financiamento. Mas eu vejo assim, que os próprios financiamentos levam que as (pequenas) produções tenham uma deficiência dentro da propriedade por que estimula o agricultor a investir mais, a se especializar mais, e no momento que se especializa ele para de produzir a sua subsistência, porque ele vai dedicar maior tempo para aquela produção que vai para o mercado (Entrevista 9, G. P., Engenheiro Agrônomo, SAM). 
Tabela 4. Rio Grande do Sul - Percentual destinado para cada finalidade do Pronaf, entre 1999 e 2008

\begin{tabular}{lcccccccccc}
\hline \multicolumn{1}{c}{ Finalidade } & $\mathbf{1 9 9 9}$ & $\mathbf{2 0 0 0}$ & $\mathbf{2 0 0 1}$ & $\mathbf{2 0 0 2}$ & $\mathbf{2 0 0 3}$ & $\mathbf{2 0 0 4}$ & $\mathbf{2 0 0 5}$ & $\mathbf{2 0 0 6}$ & $\mathbf{2 0 0 7}$ & $\mathbf{2 0 0 8}$ \\
\hline Custeio Agrícola & 90,66 & 88,79 & 85,40 & 85,40 & 68,38 & 70,39 & 70,76 & 61,94 & 60,84 & 55,28 \\
Custeio Pecuário & 3,50 & 4,85 & 5,23 & 5,23 & 2,39 & 2,54 & 5,07 & 4,52 & 6,08 & 6,97 \\
Invest. Agrícola & 3,96 & 4,49 & 5,77 & 5,77 & 22,55 & 20,33 & 18,10 & 23,08 & 22,52 & 25,92 \\
Invest. Pecuário & 1,89 & 1,87 & 3,59 & 3,59 & 6,68 & 6,74 & 6,07 & 10,46 & 10,56 & 11,82 \\
Total & $\mathbf{1 0 0}$ & $\mathbf{1 0 0}$ & $\mathbf{1 0 0}$ & $\mathbf{1 0 0}$ & $\mathbf{1 0 0}$ & $\mathbf{1 0 0}$ & $\mathbf{1 0 0}$ & $\mathbf{1 0 0}$ & $\mathbf{1 0 0}$ & $\mathbf{1 0 0}$ \\
\hline
\end{tabular}

Fonte: Bacen (2009) organizado por Ebina e Massuquetti (2010).

Outro motivo pelo qual o Pronaf custeio de lavoura não financia as pequenas produções e a diversificação rural deve-se ao fato de o financiamento ser voltado às atividades específicas dentro das unidades de produção familiares (financiamento por produto). $\mathrm{O}$ que acontece, em termos gerais, é que o projeto técnico de financiamento elaborado pelos órgãos de assistência e extensão rural quase sempre enfoca a produção de milho, soja, fumo ou outra atividade agrícola. O financiamento é específico e pontual para uma cultura, o que faz com que o agricultor familiar se especialize produzindo os cultivos para os quais há disponibilidade de crédito, em detrimento, por exemplo, da diversificação de atividades e produtos de seu sistema produtivo ou mesmo o plantio dos cultivos voltados à alimentação da família (produtos para o autoconsumo) 9 .

Pelos dados da Tabela 4 é possível verificar que, entre as modalidades do Programa no RS, o montante principal do crédito rural é aplicado em custeio agrícola. Em 1999, este chegou a $90,66 \%$ dos recursos, diminuindo nos anos posteriores e, em 2008 , usou-se $55,28 \%$ para esta finalidade, mais da metade do total dos recursos

9 A diversificação rural é entendida segundo as ideias de Ellis (2000): "A diversificação das estratégias dos agricultores é definida como um processo pelo qual as unidades domésticas constroem um incremento diversificado de suas carteiras de investimentos (portfolios) de atividades e ativos para sobreviver e para melhorar o seu padrão de vida". Ressalta-se ainda que o autor sempre se refere à diversificação em três dimensões diferentes: as inerentes ao "mundo" rural; a que há dentro das atividades agropecuárias e considerando os vínculos rural-urbano, como no caso das atividades rurais não agrícolas. aplicados, mostrando uma prioridade do crédito de custeio para lavouras. Em segundo lugar vem o investimento agrícola, com $1 / 4$ dos recursos (25,92\% em 2008); e, com percentuais menores, o investimento pecuário $(11,82 \%)$ e o custeio pecuário $(6,97 \%)$.

Essa maior alocação dos recursos do Programa no custeio de lavouras fica claro quando se analisam os dados para o RS, conforme a Tabela 5. Observa-se que, nos primeiros anos do Programa, o uso de recursos era voltado principalmente à fumicultura, com 41,74\% dos recursos (de 1999 a 2002). De 2003 em diante, ocorreu proibição do uso dos recursos do Programa para esta cultura, devido à apropriação indevida dos mesmos, que era realizada pelas grandes empresas de tabaco. Em 1999, também tem grande relevância o uso dos recursos para o plantio de milho $(29,13 \%)$ e soja $(21,46 \%)$.

Contudo, a destinação do crédito para as lavouras de milho e soja incrementam-se e chegam, em 2008, ao percentual de 40,32\% para o milho e $35,89 \%$ para a soja, refletindo a concentração de recursos nestes cultivos. Tem-se também aumento dos percentuais de recursos aplicados no trigo e no arroz em 2008, mas de maneira mais tímida do que os aplicados em milho e soja. Somando-se os percentuais de recursos usados em milho e soja, tem-se que o Programa utiliza $76,21 \%$ dos seus recursos de custeio em apenas duas culturas.

Segundo dados do IBGE $(1996,2006)$, tanto a produtividade quanto a área plantada com estas culturas aumentou de 1996 a 2006, entre os dois últimos censos agropecuários. Para o RS, por 
Tabela 5. Rio Grande do Sul - Valores destinados ao custeio das lavouras, em percentual, entre 1999 e 2008

\begin{tabular}{lcccccccccc}
\hline \multicolumn{1}{c}{ Custeio de lavoura } & $\mathbf{1 9 9 9}$ & $\mathbf{2 0 0 0}$ & $\mathbf{2 0 0 1}$ & $\mathbf{2 0 0 2}$ & $\mathbf{2 0 0 3}$ & $\mathbf{2 0 0 4}$ & $\mathbf{2 0 0 5}$ & $\mathbf{2 0 0 6}$ & $\mathbf{2 0 0 7}$ & $\mathbf{2 0 0 8}$ \\
\hline Algodão & 00,00 & 00,00 & 00,00 & 00,00 & 00,00 & 00,00 & 00,00 & 00,00 & 00,00 & 00,00 \\
Arroz & 0,76 & 1,81 & 1,56 & 1,56 & 3,33 & 4,82 & 3,98 & 4,71 & 4,76 & 4,95 \\
Batata & 0,14 & 0,13 & 0,23 & 0,23 & 0,54 & 0,54 & 0,41 & 0,43 & 0,48 & 0,43 \\
Café & 00,00 & 00,00 & 00,00 & 00,00 & 00,00 & 00,00 & 00,00 & 00,00 & 00,00 & 00,00 \\
Cana-de-açúcar & 0,01 & 0,06 & 0,10 & 0,10 & 0,07 & 0,10 & 0,17 & 0,18 & 0,23 & 0,18 \\
Feijão & 2,01 & 1,11 & 1,45 & 1,45 & 2,46 & 1,23 & 1,12 & 1,46 & 0,87 & 1,11 \\
Fumo & 41,74 & 32,78 & 28,02 & 28,02 & 00,00 & 0,01 & 00,00 & 00,00 & 00,00 & 00,00 \\
Mandioca & 0,07 & 0,01 & 0,06 & 0,06 & 0,12 & 0,09 & 0,08 & 0,10 & 0,09 & 0,09 \\
Milho & 29,13 & 37,47 & 37,16 & 37,16 & 49,86 & 43,15 & 47,71 & 46,17 & 43,62 & 40,32 \\
Soja & 21,46 & 20,61 & 24,15 & 24,15 & 31,67 & 35,68 & 32,76 & 34,61 & 33,79 & 35,89 \\
Trigo & 2,23 & 3,25 & 4,03 & 4,03 & 7,14 & 6,78 & 6,16 & 3,94 & 7,61 & 9,73 \\
Outras lavouras & - & - & - & - & - & - & 7,61 & $\mathbf{4 , 4 0}$ & $\mathbf{8 , 5 5}$ & $\mathbf{7 , 6 5}$ \\
\hline
\end{tabular}

Fonte: Bacen (2009) organizado por Ebina e Massuquetti (2010).

exemplo, a produtividade do milho aumentou $57 \%$, a da soja, $55 \%$, e a do fumo chegou a $154 \%$. No mesmo período, as áreas destas três culturas aumentaram, respectivamente: $3 \%, 41 \%$ e $93 \%$. É claro que não se pode inferir que estes efeitos são devidos ao Pronaf, mas uma parte deles talvez seja, visto que o Programa financia estes três tipos de culturas, e a agricultura familiar é responsável, em termos nacionais, por grande parte da produção destas lavouras ( $46 \%$ da produção de milho, $16 \%$ da de soja e $97 \%$ de fumos).

Estes dados deixam clara a lógica do programa no RS, que é a da especialização produtiva e da profissionalização dos agricultores. A especialização produtiva gerada pelo Pronaf é a situação em que o agricultor familiar é levado, pela política pública, a plantar o que esta financia. Ou seja, o que é mais fácil, e historicamente as instituições bancárias tem tradição de financiamento e de operacionalização. Estes dados ora apresentados corroboram outros trabalhos de pesquisa, como é o caso de Mattei (2006, 2007), Mattei et al. (2007) e Toledo (2009), que chegaram a conclusões semelhantes quanto ao que o Programa tem financiado, seus impactos no desenvolvimento rural e na produção agrícola.

Este tipo de especialização da produção gerada pelo Pronaf contribui para a redução da diversidade dos sistemas produtivos e reduz a autonomia das unidades familiares, minando uma das principais características dos processos de reprodução social da agricultura familiar, que é a diversificação de cultivos por ela implementados e manejados (CARNEIRO, 1997; ELLIS, 2000).

Não raro, esta especialização produtiva acaba por deslocar espacialmente e temporalmente a produção de pequenos cultivos, lavouras não comerciais, pequenas criações animais e alimentos para consumo doméstico - os agricultores delegam as melhores áreas de terras e a maior parte do seu tempo de trabalho no manejo destas culturas. Neste sentido, nossas evidências apontam que os agricultores financiam o plantio de milho ou soja, mas as pequenas produções e o cultivo de alimentos ficam relegados a um plano secundário dentro da dinâmica das unidades de produção (GAZOLLA, 2004).

Pelos dados discutidos fica clara essa dinâmica da especialização produtiva dos agricultores, principalmente dos mais consolidados frente às grandes agroindústrias agroalimentares, o que é corroborado por vários outros estudos e pesquisas (ABRAMOVAY e VEIGA, 1999; ANDRADE DA SILVA, 1999; FERREIRA et al., 2001 e GUANZIROLI, 2007). Uma explicação plausível para este fato foi fornecida com eloquência por Mattei (2007). Segundo o autor, isso ocorre devido ao fato de o Pronaf ter maior destinação 
Tabela 6. Rio Grande do Sul - Valores destinados ao investimento agrícola, em percentual, entre 1999 e 2008

\begin{tabular}{lcccccccccc}
\hline \multicolumn{1}{c}{ Invest. Agrícola } & $\mathbf{1 9 9 9}$ & $\mathbf{2 0 0 0}$ & $\mathbf{2 0 0 1}$ & $\mathbf{2 0 0 2}$ & $\mathbf{2 0 0 3}$ & $\mathbf{2 0 0 4}$ & $\mathbf{2 0 0 5}$ & $\mathbf{2 0 0 6}$ & $\mathbf{2 0 0 7}$ & $\mathbf{2 0 0 8}$ \\
\hline Animais de serviço & 00,00 & 0,04 & 3,97 & 3,97 & 0,15 & 0,08 & 0,24 & 0,52 & 0,95 & 0,78 \\
Formação culturas perenes & 3,70 & 5,85 & 1,01 & 1,01 & 2,52 & 3,31 & 5,49 & 7,10 & 6,19 & 3,43 \\
Máquinas e equipamentos & 11,63 & 5,63 & 8,43 & 8,43 & 21,99 & 35,75 & 40,94 & 53,66 & 62,44 & 74,20 \\
Melhorias nas explorações & 19,96 & 12,86 & 46,83 & 46,83 & 43,26 & 31,29 & 23,37 & 15,93 & 13,71 & 9,56 \\
Outras aplicações & 64,47 & 75,44 & 39,55 & 39,55 & 31,52 & 28,25 & 27,66 & 19,36 & 12,73 & 8,43 \\
Veículos & 0,25 & 0,18 & 0,21 & 0,21 & 0,56 & 1,32 & 2,29 & 3,43 & 3,98 & 3,59 \\
\hline
\end{tabular}

Fonte: Bacen (2009) organizado por Ebina e Massuquetti (2010).

de recursos concentrada nos antigos grupos C, D e E, que são representados pelos agricultores com maior renda bruta anual e mais estruturados em termos produtivos e econômicos.

A destinação dos recursos a estes segmentos também pode ser ilustrada pelo exemplo empírico do município de Frederico Westphalen, que fica na microrregião pesquisada. Em 2000, $44 \%$ dos recursos do Pronaf foram investidos no milho, 24\% no Pronaf Rotativo ${ }^{10}$ (que também financiava, de maneira geral, a implantação de lavouras de milho, soja e fumo), $17 \%$ na soja, e $10 \%$, no fumo, demonstrando a seleção e a especialização de atividades produtivas.

Os dados da Tabela 6 trazem os recursos de investimento agrícola no RS. Nota-se, nos primeiros anos da política, de 1999 a 2000, que os recursos voltaram-se principalmente às chamadas outras aplicações, respectivamente com $64,47 \%$ e 75,44\% dos recursos. De 2001 até 2003, os recursos ainda continuavam sendo aplicados nessa finalidade (cerca de 1/3); porém, a maioria é usada na rubrica melhoria das explorações familiares, com quase 50\% dos valores aplicados. De 2004 a 2008, os recursos do Pronaf voltam-se à rubrica máquinas e equipamentos, saindo de $35,75 \%$ em

10 Esta linha de financiamento do Programa não existe mais atualmente. O Pronaf Rotativo destinava recursos para a unidade de produção e os agricultores os utilizavam de acordo com as suas necessidades; porém, na prática, a grande parcela dos recursos foi utilizada para poucas lavouras, como os dados demonstram para o município em questão. Esta modalidade era chamada de rotativo, pois assim que o agricultor efetuasse o pagamento dos seus débitos, no ano seguinte, os recursos entravam na sua conta novamente de forma automática e sem burocracia.
2004 (aumentando progressivamente de 2005 a 2007) e, em 2008, dão um salto, chegando a $72,20 \%$, concentrando-se neste item.

Isso demonstra que os recursos de investimento agrícola do Programa, que inicialmente tinham usos mais diversos nas unidades, com o tempo assumem a mesma lógica do custeio agrícola e vão concentrando-se em somente um uso - no incremento tecnológico no campo. Isso ocorre devido a dois aspectos. Primeiro, há de se considerar que, em resposta à crise de alimentos de 2008, o governo federal criou o Pronaf Mais Alimentos ${ }^{11}$. Com este, o MDA estima ter aumentado em 7,8 milhões de toneladas a produção de alimentos e a produtividade da agricultura familiar, que cresceu após a implantação dessa modalidade. Segundo o Plano Safra 2009/2010, por exemplo, a produtividade do leite aumentou $18,25 \%$, a da mandioca, $13,4 \%$, a

\footnotetext{
11 Não se deve confundir o Pronaf Alimentos com o Pronaf Mais Alimentos. O Pronaf Alimentos era uma modalidade de financiamento de custeio que foi criada em 2003, em sintonia com o Programa Fome Zero. Visava a concessão de microcrédito para combater a pobreza nos espaços rurais e assegurar a geração da produção para autoconsumo para alimentação das famílias rurais e a venda dos excedentes para a sociedade. O objetivo era criar condições para que os agricultores mais carentes desenvolvessem atividades para sua "subsistência" e garantia de renda com a venda de alguns produtos. Com a crise mundial de alimentos de 2008, o Estado criou o Pronaf Mais Alimentos, que é uma linha de financiamento de investimento. Essa modalidade é diferente da primeira, pois visa dar condições para que agricultores recuperem a sua infraestrutura rural para produção de alimentos, por meio da aquisição de veículos agrícolas, tratores e outros investimentos em capitais fixos das propriedades rurais. Ver os últimos planos safras (2008/2009, 2009/2010 e 2011/2012) para obter mais informações sobre a proposta do Pronaf Mais Alimentos.
} 
do milho, 9,3\%, a do feijão, 9,4\%, do café, 7,6\%, do arroz, $6,3 \%$ e do trigo, $5,4 \%$.

No entanto, quando se aprofunda a análise dos usos dos recursos desta linha se verá que a grande parte dos mesmos vão ser usados para o investimento agrícola, basicamente em máquinas e equipamentos, nos quais a rubrica destinada à aquisição de veículos agrícolas é a maior (principalmente tratores). Outras investigações recentes também salientam essa lógica do Programa. É o caso do estudo de Stoffel et al. (2011) para o estado do RS. Esse trabalho aponta que, em 2000, os valores destinados para essa modalidade eram de $\mathrm{R} \$ 23.577 .616,00$, tendo ocorrido um crescimento vertiginoso, alcançando, em 2009, cerca de $\mathrm{R} \$ 812.736 .003,00$. O crescimento no período foi de aproximadamente $\mathrm{R} \$ 789$ milhões de reais, sendo aplicados principalmente nas rubricas máquinas, equipamentos e veículos agrícolas.

O segundo fator é que o Pronaf custeio de lavouras coloca a maioria dos recursos em culturas como a soja e o milho, estimulando aumentos em área e produtividade. Com o tempo, é obvio que os agricultores precisariam de melhorias em sua infraestrutura rurais (maquinários, equipamentos e veículos agropecuários) para continuarem incrementando o plantio destas culturas. Assim, os recursos de investimento a partir de 2008, principalmente, voltam-se também a este fim. Em decorrência dessa lógica do Programa forma-se um círculo vicioso na aplicação dos recursos do crédito, em que atualmente estão totalmente integrados os recursos de custeio com os de investimento, pois os dois vão estimular as mesmas atividades produtivas, aprofundando a destinação do crédito em torno de uma lógica de desenvolvimento produtivista e setorial da agricultura familiar (AQUINO e SCHNEIDER, 2010).

É devido ao fato de o Programa estimular esse padrão de desenvolvimento agrícola já preexistente nesse local, baseado na externalização tecnológica e na especialização da produção, que se diz que ele está fazendo "mas de lo mismo" parafraseando a expressão usada por Schejtman e Berdegué (2003). Isso significa que o Pronaf continua a aprofundar uma lógica de desenvolvimento preexistente que é a responsável pela fragilização de muitos agricultores. Com o apoio à esfera estrita da produção, a tendência é que haja um processo ainda maior de vulnerabilidade destas unidades, devido à mercantilização crescente dos seus processos produtivos (como vem ocorrendo desde a década de 70) e à dependência externa de uso de insumos e tecnologias, cada vez mais caros, levando os agricultores a um processo de squeeze $^{12}$, como já foi bem demonstrado por Ploeg et al. (2000).

No intuito de analisar até que ponto o Pronaf está apoiando as pequenas produções, os cultivos e criações não mercantis e as atividades de diversificação rural da agricultura familiar são abordados na próxima seção. Nela, examinase o modo como o Pronaf está apoiando estas pequenas iniciativas e práticas das famílias, fazendo-se uma distinção entre os efeitos gerados nas suas duas linhas básicas de ação, o crédito de custeio e o de investimento.

\section{Como o Pronaf apoia a agricultura familiar? Diversificação rural, pequenas atividades agropecuárias e produção para o autoconsumo}

Em que pesem algumas contradições apontadas anteriormente em relação ao tipo de fortalecimento que o Programa está gerando na agricultura familiar, deve-se reconhecer também que esta política é importante para a reprodução social e a manutenção dos agricultores nos espaços rurais. Nesta seção, evidencia-se que o Pronaf exerce um tipo específico de fortalecimento dos

\footnotetext{
12 A tradução para a palavra squeeze significa "aperto", "compressão" ou "estreitamento". É a situação gerada a partir do processo de modernização da agricultura, em que os agricultores são comprimidos entre, de um lado, o aumento dos custos de produção com a aquisição de insumos e tecnologias externas à propriedade e, de outro, pela queda nos preços dos principais produtos agrícolas e alimentos, gerando um processo de queda constante na rentabilidade das suas atividades produtivas e econômicas.
} 
agricultores, que passa pelo financiamento de atividades produtivas e econômicas que levam as propriedades rurais a se diversificarem internamente e setorialmente. Evidencia-se que esta política, mesmo de uma forma periférica em alguns casos, e de forma direta em outros, tem estimulado algumas das pequenas produções e criações, a alimentação básica das famílias e fortalecido um tipo de agricultura mais diversificada.

Inicia-se analisando alguns dados dos censos agropecuários do IBGE (1996, 2006). Segundo essas informações, as culturas para alimentação básica familiar e da sociedade em geral também tiveram aumentos em produção e área, algumas delas, porém, menos pronunciados do que os vistos pelas culturas mercantis, como discutido anteriormente. Por exemplo, em termos nacionais, a produção do feijão aumentou $114 \%$, e a área, $44 \%$; para a mandioca, as elevações foram de $77 \%$ e $119 \%$; para o arroz, houve aumento de $17 \%$ na produção, mas queda de $-19 \%$ na área; para o trigo, os aumentos foram de $58 \%$ e $45 \%$; já para a laranja, os recuos foram de $-85 \%$ e $-47 \%$, respectivamente, entre os dois censos agropecuários.

$\mathrm{Na}$ região Sul, para estes produtos, se observa a mesma tendência verificada para o País, entretanto, com quedas mais bruscas ainda de produção e área de algumas culturas importantes à alimentação. Por exemplo, o feijão foi o mais pronunciado, pois registrou queda de -98\% na produção e de $-99 \%$ na área cultivada; já a mandioca teve altas de $50 \%$ e $41 \%$; quanto ao arroz, houve elevação de $20 \%$ na produção, mas queda de $-7 \%$ na área plantada; para o trigo, aumentos de $54 \%$ e $46 \%$; e a laranja, baixa de $-86 \%$ na produção, mas alta de $52 \%$ na área, respectivamente, entre os dois últimos censos agropecuários.

Estes dados demonstram que, nesse período de dez anos, esses cultivos para alimentação básica dos agricultores e da sociedade brasileira tiveram um desempenho minorado se comparado aos dos cultivos dinâmicos de mercados como o milho, a soja e o fumo. Como se argumentou anteriormente, não se podem aferir os efeitos diretos do Pronaf sobre estas culturas, mas sabese que a agricultura familiar é produtora de uma parcela expressiva destes alimentos e que o Programa financia estas lavouras no País e no RS, tendo efeito sobre as mesmas, que é difícil de ser mensurado somente com os dados do IBGE.

Observando-se os dados contidos na Tabela 5 apresentada anteriormente, nota-se que os recursos destinados pelo Pronaf crédito de custeio para estas lavouras são inferiores em relação às que mais recebem, como é o caso do milho $(40,32 \%)$ e da soja $(35,89 \%)$, em 2008 . Culturas como o arroz receberam o máximo de $4,95 \%$ dos recursos em 2008; a batata recebeu $0,48 \%$ em 2007, o feijão, $1,46 \%$ em 2006, a mandioca, $0,12 \%$ em 2003, e o trigo, $0,93 \%$ em 2008. Estes dados demonstram a tendência do Programa em privilegiar as atividades produtivas de mercados, em detrimento das culturas que têm por objetivo a diversificação rural e a alimentação básica dos agricultores e da própria sociedade brasileira.

A pesquisa de campo desenvolvida na região do Médio Alto Uruguai (RS) evidenciou que o processo de apoio aos pequenos cultivos/criações, a produção de alimentos básicos e diversificações rurais acontece de forma indireta na linha do Pronaf crédito de custeio. O agricultor familiar, em alguns casos, acessa o financiamento para a produção de grãos como o milho e a soja. Este implanta a cultura que financiou, só que não coloca toda a quantidade dos recursos acessados.

O agricultor sempre "separa" parte significativa dos insumos que comprou para executar a implantação de alguma outra pequena cultura para a alimentação, como uma horta, plantio de feijão, de arroz, amendoim, mandioca ou outra cultura qualquer para a alimentação da família. O que ocorre é um deslocamento de parte dos recursos que o Pronaf financiou para a implantação da cultura principal, para que haja o fortalecimento destas outras culturas. Por isso que, indiretamente, o Pronaf tem estimulado a diversificação agrícola e os pequenos cultivos agroalimentares.

Essa racionalidade dos agricultores de "protegerem" os seus pequenos cultivos agropecuários 
e a produção de alimentos básicos evidencia-se nos relatos de um agricultor que executou este deslocamento dos recursos para implantar uma horta. No segundo caso, de um dirigente sindical da Fetraf-Sul que confirma que a entidade orienta os agricultores a executarem essa operação.

(O Pronaf) ajuda em todas as partes. Tem o adubo [...] que tem que colocar em toda a propriedade. Se tu vai semear uma verdura bota o adubo, ele ajuda em todas as partes (Entrevista 16, R. D., Agricultor familiar).

$\mathrm{O}$ agricultor tem que saber que busca o crédito agrícola para produzir o alimento. Não investir só na soja, mas ele tem que pegar alguns sacos de adubo e um pouquinho destes recursos e produzir os outros produtos como o amendoim, a mandioca, a batata e os outros produtos de subsistência [...] (Entrevista 18, A. R. A., Representante Sindical, Fetraf-Sul).

O Pronaf crédito de custeio também tem papel importante no fortalecimento da produção de milho nas unidades. O milho é um dos produtos mais financiados pelo Pronaf crédito de custeio, como demonstram as Tabelas 3 e 5, apresentadas anteriormente. $\mathrm{O}$ milho também tem caráter da alternatividade produtiva, como já se mencionou anteriormente, pois ele pode ser tanto vendido quanto consumido pelos animais ou pela família, dependendo das condições familiares e dos mercados. Além disso, na agricultura familiar, o milho tem vários usos na unidade de produção (alimentação de pequenos animais, como cabras, aves, suínos, ovelhas, consumo da família na forma de milho verde, canjica de milho ou polenta).

É dessa forma que o Programa fortalece as famílias, quando financia a produção de milho e este fica em poder dos diferentes usos familiares. Neste sentido, os dados levantados a campo parecem indicar um desacordo com os resultados de pesquisas de outros autores como Abramovay e Veiga (1999), Andrade da Silva (1999), Ferreira et al. (2001) e, mais recentemente, o estudo de Guanziroli (2007), que afirmaram que o Pronaf tem fortalecido somente os agricultores familiares integrados aos mercados, via complexos agroindustriais da soja, do milho (avicultura e suinocultura) e do fumo.

Na região em análise, isso deve ser relativizado, pois uma percentagem muito significativa do milho produzido dentro das unidades familiares é destinada ao autoconsumo intermediário (ou seja, é utilizada na alimentação dos animais e pequenas criações). Este vai fomentar a criação e engorda de suínos, aves, bovinos, caprinos e outros pequenos animais que irão servir para a alimentação das famílias, especialmente das mais pobres, que não estão integradas com os complexos agroindustriais. $\mathrm{Ou}$, ainda, estes pequenos animais podem ser comercializados, recebendo-se uma renda extra pelas suas vendas.

O papel do milho no fortalecimento é explicitado na entrevista com um agrônomo da Emater, que destaca o papel desta cultura na produção de carne, leite e ovos para a alimentação das famílias.

No nosso município o Pronaf financia mais o milho do que qualquer outra cultura. Então ele faz a produção para autoconsumo porque é desse milho que ele vai produzir a galinha ao redor de casa, ele vai produzir o leite, carne e ovos em cima disso. Então eu acho que o milho é um parâmetro importante para a propriedade, para a produção de alimentos. Neste sentido, eu acho que ele está auxiliando de forma preponderante para a manutenção da agricultura familiar (Entrevista 12, G. S., Engenheiro Agrônomo, Emater).

Outro aspecto é o da multiplicação das linhas de financiamento do Pronaf, visando contemplar o processo de diversificação rural das famílias. É o caso, por exemplo, do Pronaf Alimentos que foi criado na safra 2003/2004 e objetivava incentivar a produção básica de alimentos da agricultura familiar. Segundo o Plano Safra 2003/2004 (2003, p. 4), “o Pronaf Alimentos visa estimular a produção de cinco alimentos básicos da mesa dos brasileiros - arroz, feijão, mandioca, milho e 
trigo". Verificou-se que, em alguns casos, o Pronaf Alimentos não estava fortalecendo a produção destes cinco alimentos básicos. Observou-se que os agricultores orientados pelos sindicatos e escritórios municipais da Emater usam os recursos para outros fins e não os aplicam na produção dos alimentos que essa modalidade visava fortalecer.

$\mathrm{Na}$ operacionalização desta linha de financiamento, constataram-se inúmeros "descaminhos" em relação aos princípios e objetivos com que esta política foi formulada e planejada pelo Estado. São exemplos: a aplicação dos recursos, como o investimento na construção de pocilgas para integração agroindustrial, não aquisição de animais (matrizes) para atividade leiteira, usos para a implantação de lavouras e criações animais diferentes dos objetivos estipulados.

Os recursos, em alguns casos, são deslocados para uma atividade produtiva com maior potencial de retorno financeiro e que tenha comercialização garantida no local. Constatou-se este direcionamento dos recursos do Pronaf Alimentos, sendo que os atores sociais chegam a formular que o Pronaf Alimentos "virou um Pronaf normal", numa alusão de que esta modalidade de financiamento não conseguiu se distinguir das outras, pois continua a financiar as atividades historicamente institucionalizadas na região, como é o caso da suinocultura integrada, da produção de grãos e commodities.

Esta lógica do Pronaf Alimentos de fortalecer os agricultores da mesma maneira que um Pronaf "normal" (de custeio de lavoura, por exemplo), fica explícita no relato de um agrônomo da Emater. $\mathrm{O}$ entrevistado usa a seguinte expressão para argumentar sobre este processo: "é claro que tem uma lógica do ponto de vista teórica muito boa, mas na prática eu acho que não deu grandes alterações na subsistência".

[...] O Pronaf Alimentos se desvirtuou muito. O Pronaf alimentos realmente vem naquela lógica de tentar reforçar a subsistência, mas o que eu sinto no Alimentos ainda é que na primeira vez que saiu aqui se desvirtuou muito. Por quê? Qual é o problema? [...] Ainda tem muito rolo nestas histórias, desvios. Muito desvio do princípio de aplicação do Pronaf Alimento, porque o agricultor quer investir o dinheiro naquilo que ele acha que é importante. Então, por exemplo, o Alimento não podia permitir outras coisas e foi mudando, foi mudando e virou um Pronaf normal. Então eu ainda acho que é claro que tem uma lógica do ponto de vista teórico, mas na prática eu acho que não deu grandes alterações na subsistência [...] (Entrevista 22, R. B., Engenheiro Agrônomo, Emater).

Já quando se analisaram os efeitos do Pronaf crédito de investimento, observou-se dois tipos de resultados. O primeiro é indireto e está na forma de implantação de infraestruturas rurais nas unidades de produção, que vão influenciar a produção de forma acessória, como é apresentado na Tabela 3. Na Tabela 4, por exemplo, nota-se que a infraestrutura rural está no que se chama de investimento agrícola e pecuário, que receberam, respectivamente, $25,92 \%$ e $11,82 \%$ dos recursos em 2008.

O estímulo ocorre por meio do fortalecimento da estrutura de produção das unidades com a aquisição de máquinas e equipamentos para a agregação de valor em produtos da agroindústria familiar, na aquisição de ordenhadeiras de leite, compra de matrizes animais para leite e suínos, engenhos de cana (moendas), recipientes para a fabricação de açúcar mascavo ("tachos"), pequenas máquinas para panificação, entre outras coisas, que desempenham papéis importantes na obtenção de alimentos e de pequenos produtos, mesmo que o seu impacto seja indireto.

O trecho de uma entrevista com um secretário municipal da agricultura demonstra este processo de apoio da produção de alimentos e de diversificação rural das propriedades, mesmo sendo de uma forma indireta, como o entrevistado se refere.

Se tu pegar os projetos financiados tu vai encontrar em todos eles características de fortalecimento da produção de alimentos, 
de transformação para o autoconsumo, você vai ver nitidamente em todos os projetos. Praticamente todos os agricultores financiam alguma coisa: um tacho, um engenho de cana, alguma outra coisa de agregação de valor. Indiretamente para esse fortalecimento, ou seja, o agricultor ainda mantém viva aquela questão da produção de alimentos para o consumo, mesmo quando ele vai financiar alguma coisa que é Investimento lá para o leite, mas de alguma forma ele tenta colocar algum produto ou equipamento neste sentido (Entrevista 9, G. P., Engenheiro Agrônomo, SAM).

O segundo efeito é um estímulo de forma direta, no qual ocorre um aumento real da produção de alimentos e das pequenas diversificações por meio do financiamento. $\mathrm{Na}$ pesquisa observou-se serem importantes às atividades da fruticultura (implantação de pomares) e do leite (aquisição de matrizes) como estratégias de fortalecimento do processo de diversificação, pois as duas recebem parcelas significativas de recursos do Programa na região pesquisada (Tabela 3). Na Tabela 6, os mesmos dados são apresentados para todo o RS. Foi possível observar que a rubrica "implantação de culturas perenes", onde está imersa a fruticultura, recebeu, em 2008, 3,43\% dos recursos do investimento agrícola. Segundo Ebina e Massuquetti (2010), a rubrica de "aquisições de animais", contida nos recursos de investimentos, onde está a atividade leiteira, recebeu em 2008, $38,15 \%$ dos recursos, na região Sul.

A fruticultura e o leite são importantes aos agricultores por dois motivos. Primeiro: as duas têm alternatividade, como se discutiu anteriormente. Segundo: devido ao fato de elas agirem na direção da diversificação rural, afastando os agricultores dos mercados dependentes e externalizados dos grãos e commodities. O financiamento da atividade leiteira possibilita as famílias venderem-no e terem renda mensal ou consumi-lo in natura. Do leite também se pode obter vários produtos por meio da agroindústria (queijos, nata, manteiga, iogurte), que podem servir de alimentação ao grupo doméstico ou serem vendidos. O leite é importante ainda à segurança alimentar das famílias, principalmente as com filhos pequenos e as mais pobres.

No caso da fruticultura, verificou-se que o Pronaf investimento tem financiado projetos de implantação de diversas espécies de frutas como laranja, pêssego, figos, morangos, videiras e outras frutíferas em menor escala, como demonstra a Tabela 3. A produção de frutas tem os papéis de diversificar a produção rural; podem também ser consumidas, transformadas pela agroindustrialização para a venda (fabricam-se geleias, doces, compotas, doces em calda, frutas cristalizadas, doces em pasta). Verificou-se, inclusive, que estas são destinadas para a venda in natura ou processadas, e que os mercados que os agricultores constroem não são dependentes como os de grãos ou das integrações as grandes agroindústrias existentes na área da suinocultura e avicultura.

Pode-se dizer que há uma diferenciação no impacto das duas linhas básicas de atuação do Programa, o custeio e o investimento. O crédito de custeio é mais voltado às culturas dinâmicas e mercantis como o milho, a soja e o fumo (este último no início do Programa). Por outro lado, o Programa financia o milho, que tem importância muito grande em termos de alimentação animal, das famílias e os diferentes usos. Como demonstra o estudo de Mattei (2007), essa linha do Pronaf tem bem mais recursos e acessos pelos agricultores do que a de investimento, que é destinada à infraestrutura rural.

Segundo Mattei (2007), "em termos dos contratos, na safra de 1999, o crédito de custeio respondia por $84 \%$ destes, enquanto o crédito de investimento participava com apenas 16\%". Esta tendência começa a mudar somente em 2005, quando o custeio reduziu sua participação no número de contratos para $58 \%$, enquanto o investimento passou para $42 \%$. Desse modo, o custeio tem maior relevância sobre os processos produtivos dos agricultores familiares.

Geralmente, os financiamentos tanto das linhas do crédito de custeio quanto de inves- 
timento não visam estimular as pequenas produções, criações e diversificação rurais como estratégias relevantes de reprodução social das famílias. Na maioria das vezes, visam a inserção mercantil e a produção de grãos e commodities agrícolas. O apoio a estas atividades ocorre como se fosse uma consequência secundária do estímulo das atividades produtivas principais e mercantis. É por este motivo que se insiste que o seu fortalecimento é gerado de forma indireta e periférica na dinâmica das unidades familiares.

Também deve ser considerado que existe uma história produtiva do RS e, em particular, da região pesquisada, que está ligada à produção de grãos e commodities agrícolas. Esta está profundamente institucionalizada nos movimentos sociais, nos agricultores e nas instituições de desenvolvimento rural (NORTH, 1994). Este é um dos motivos estruturais que impede a evolução do Pronaf no sentido de ser uma "ferramenta" mais eficaz de promoção do desenvolvimento rural, muito maior do que ele já é na atualidade.

Para que o Pronaf se torne uma política mais voltada ao desenvolvimento rural, algumas mudanças parecem necessárias. Estas modificações implicariam que o Programa continue o processo de incentivo à produção das unidades familiares, como ele já vem realizando, que é fundamental, mas também incorporar as dimensões das necessidades familiares, os princípios da diversificação rural e territorial, inovações em financiamento de cadeias produtivas onde há nichos de mercados, preocupar-se com a segurança alimentar tanto da agricultura familiar quanto da sociedade (os produtos da agricultura familiar podem servir de alimentos à sociedade, principalmente aos mais pobres, como mostra a experiência do Programa Fome Zero) e incorporar as atividades rurais não agrícolas como importantes ao estímulo da agricultura familiar.

Isso se reveste de extrema importância, pois no momento que as ações do Programa incorporarem o fortalecimento do grupo familiar, elas estarão levando em conta não somente o incremento produtivo e econômico dos cultivos, mas também as outras dimensões da agricultura familiar, como a ambiental, as aspirações dos membros do grupo familiar, as estratégias individuais e coletivas da família, as pequenas produções não mercantis e de alimentos básicos, a produção para autoconsumo, a pluriatividade, a segurança alimentar e nutricional, a agregação de valor aos alimentos etc. Com isso, o Pronaf estaria fortalecendo o grupo familiar, que na agricultura familiar é a célula básica de reprodução social e econômica desta forma de produção e trabalho e que empresta os seus diversos sentidos e estratégias utilizadas para sua manutenção nos espaços rurais.

Com estas mudanças, o Programa estaria mais alinhado também com outras politicas públicas de desenvolvimento rural que têm foco nos agricultores familiares. Por exemplo, políticas como o PAA e o PNAE (que deve comprar no mínimo 30\% dos alimentos dessa categoria social) poderiam ser melhor viabilizadas junto à uma agricultura familiar diversificada e policultora de alimentos. Como se procurou demostrar durante o trabalho, se prevalecer à dinâmica principal do Programa, que é a de continuar fomentando principalmente as culturas de grãos e commodities agropecuárias, corre-se o risco de políticas governamentais de aquisições de alimentos com o PAA e o PNAE terem dificuldades em encontrar os alimentos necessários para a comercialização a estes programas institucionais na região do Médio Uruguai.

\section{Conclusões: a necessidade de avanços no Pronaf}

Desde o surgimento do Pronaf, em 1996, o Programa se transformou e trouxeinquestionáveis efeitos positivos ao desenvolvimento rural brasileiro, tais como contribuir para melhorar as condições de produção e segurar os agricultores no campo, aumentar a oferta de alimentos, aumentar a produtividade de alguns produtos, gerar ocupação e empregos, que se refletem positivamente em alguns indicadores econômicos 
e produtivos rurais, entre outros efeitos benéficos que os estudos têm destacado.

Entretanto, em face do que foi apresentado neste artigo, considera-se necessário que o Programa necessita dar "um passo à frente" em sua evolução política e ajustar o foco nas reais necessidades da agricultura familiar em suas várias dimensões, como nas questões ambientais, nas estratégias coletivas das famílias, o fomento às suas pequenas atividades econômicas $\mathrm{e}$ produtivas, incentivos à produção de alimentos (o seu autoconsumo, que está relacionado à segurança alimentar e nutricional), incorporar as atividades rurais não agrícolas e financiar empreendimentos que fortaleçam a célula básica da agricultura praticada em pequena escala - a família.

Cotejando o formato atual do Pronaf com os seus objetivos iniciais, é possível afirmar que se trilhou por atalhos em sua evolução, o que fez com que, em alguns casos, não tenha conseguido atingir os objetivos do desenvolvimento rural estabelecidos em seu início. Entre as limitações do programa é possível arrolar a intensificação do cenário já preexistente de mercantilização produtiva imposta pela produção de grãos e commodities na região pesquisada e, de certa forma, no RS.

As políticas públicas como o Pronaf muitas vezes são planejadas de forma a promover alternativa a este tipo de desenvolvimento (por exemplo, a diversificação das modalidades de financiamento do Programa em várias frentes, como na agroecologia, mulher, agroindústria familiar, turismo, entre outras, só para citar algumas). Porém, quando da sua operacionalização junto aos agricultores ocorrem situações inusitadas e, por vezes, a política acaba distorcida por variados motivos pelos atores sociais resultando em efeito contrário ao desejado. Isso é um pouco o que está acontecendo com o Pronaf em relação aos seus "efeitos inesperados" (LONG e PLOEG, 1994).

Como conclusões mais pontuais, o estudo aponta para três conjuntos de efeitos principais do Pronaf, que estão interligados. Um primeiro é que o Programa está financiando as atividades produtivas habituais de grãos e commodities dos agricultores. Os dados demonstram que, para o RS, somente dois cultivos, a soja e o milho, são responsáveis por mais de $76 \%$ dos recursos destinados ao custeio para o estado. Essas culturas historicamente têm um legado de pouco valor agregado aos agricultores familiares, baixos preços recebidos e mercados em que eles dependem de outros intermediários como empresas, cerealistas ou cooperativas tritícolas para realizar a venda da produção. Nesse cenário, a perda da autonomia reprodutiva dos agricultores para estes outros agentes é um dos principais efeitos gerados.

Essa dinâmica do Pronaf também gera outros resultados junto às famílias, como a crescente fragilização social, a mercantilização das unidades familiares (há o aumento da externalização da unidade produtiva, devido à compra de insumos e tecnologias para essas culturas de fora das propriedades) e a especialização produtiva em direção a um elenco restrito de atividades agropecuárias desenvolvidas. Neste tipo de desenvolvimento o fortalecimento da produção de alimentos básicos, a diversificação rural e as pequenas produções/criações familiares não têm lugar. Ao longo do trabalho procurou-se deixar claro que esta dinâmica de desenvolvimento rural é a principal vis à vis a segunda apresentada, inclusive em volume de recursos e em resultados alcançados pelo Programa.

Na segunda dinâmica do Pronaf se observou que este tem estimulado um tipo de desenvolvimento rural que passa pelo efeito benéfico dos seus recursos sobre a produção de diversos alimentos básicos (arroz, feijão, leite, frutas etc.), por processos de diversificação da pauta de atividades rurais (os pequenos cultivos e criações) e apoio a pequenas iniciativas agropecuárias como, por exemplo, a implantação de uma horta, pomar, agroindústrias. Contudo, esse tipo de fortalecimento que a política gera tem como características centrais ser periférico e secundário nas famílias investigadas, dado o pequeno volume de recursos alocados a estes fins. Por exemplo, quando somados os valores do crédito 
de custeio alocados na produção de alimentos nas rubricas como outras lavouras, trigo, arroz e feijão, tem-se que apenas $21,19 \%$ dos mesmos são dessa forma utilizados, comprovando que essa dinâmica do Programa é minorada em relação à outra antes discutida.

Como demonstrou-se, muitas vezes, o agricultor realoca parte dos recursos que deveriam ser aplicados nas culturas, como milho e soja, e os aplica nestas suas pequenas culturas e criações. Isso é preocupante, pois estas atividades são importantes à manutenção da agricultura familiar e muitas delas estão relacionadas à sua segurança alimentar e nutricional, bem como da sociedade brasileira como um todo, visto que, se estes alimentos forem produzidos com excedentes, eles podem ser escoados para alimentar a população urbana, ou mesmo servir para serem comercializados via programas institucionais como o PAA ou PNAE, gerando renda extra para agricultores e construindo novos mercados diferenciados dos habituais de grãos e commodities.

Um terceiro conjunto de observações e dados aponta que o uso dos recursos do custeio e investimento agrícola atualmente caminham na mesma direção de aplicação. Como demonstrouse, os recursos de custeio são aplicados principalmente em lavouras temporárias de grãos e commodities, historicamente na região e no estado do RS. Atualmente com o crescente uso dos recursos de investimento (e agora por meio da modalidade do Pronaf Mais Alimentos, que incrementou ainda mais este tipo de crédito), estes são usados para a aquisição de máquinas, equipamentos e veículos agrícolas para fornecer infraestrutura rural às mesmas culturas de soja $e$ milho financiadas pelo custeio. Forma-se, assim, um circulo vicioso em torno do uso dos recursos, pois as duas modalidades de financiamentos unem-se em torno das mesmas atividades econômicas, especializando e mercantilizando crescentemente a agricultura familiar local.

\section{Referências bibliográficas}

ABRAMOVAY, R. e VEIGA, J. E. Novas Instituições para o Desenvolvimento Rural: o caso do Programa Nacional de Fortalecimento da Agricultura Familiar (PRONAF). Texto para discussão n. 641. Brasília-DF, Convênio FIPE/IPEA 07/97. Abril de 1999, 51p.

ANDRADE DA SILVA, E. R. Programa Nacional de Fortalecimento da Agricultura Familiar: Relatório Técnico das Ações Desenvolvidas no Período 1995/1998. Texto para discussão n. 664. Brasília-DF. IPEA, 1999, 48p.

AQUINO, J. R. e SCHNEIDER, S. 12 anos da política de crédito do PRONAF no Brasil (1996-2008): uma reflexão crítica. VIII Congresso Latino-Americano de Sociologia Rural. Anais em CD-ROM do VIII Congresso da ALASRU... Porto de Galinhas/PE, v. 1. 20p., 2010.

AQUINO, J. R., RADOMSKY, G. F. W., SPHOR, G., RADOMSKY, C. W. e SCHNEIDER, S. Dimensão e localização do público potencial do Pronaf " $B$ " no Brasil: uma análise a partir do Censo Agropecuário de 2006. 49o Congresso da Sociedade Brasileira de Economia, Sociologia e Administração Rural. Anais... Belo Horizonte/MG, 18p., julho de 2011.

CARNEIRO, M. J. Política pública e agricultura familiar: uma leitura do Pronaf. Revista Estudos Sociedade e Agricultura. Rio de Janeiro-RJ, Revista Semestral, abril de 1997, n. 8, p. 70-82.

CODETER. Conselho de Desenvolvimento Territorial do Médio Alto Uruguai. Retirado de <www.fw.uri.br/ territorio > . Acesso em março de 2010.

CONTERATO, M. A., GAZOLLA, M. e SCHNEIDER, S. A dinâmica agrícola do desenvolvimento da agricultura familiar no Alto Uruguai, Rio Grande do Sul: suas metamorfoses e reações locais. In: TONEAU, J. F; SAUBORIN, E. (Orgs.). Agricultura familiar: interações entre políticas públicas e dinâmicas locais. Editora da UFRGS: Porto Alegre - RS. pp. 13 - 54, 321 p., 2007.

COPETTI, L. D. Fatores que dificultam o acesso dos agricultores as políticas de crédito rural: o caso do Pronaf-Crédito no Município de Alegria/RS. Dissertação de Mestrado. Universidade Federal do Rio Grande do Sul, Porto Alegre. 206 f., 2008.

EBINA, R. K. e MASSUQUETTI, A. Análise do Pronaf na Região Sul do Brasil: um estudo do Rio Grande do Sul no período 1999 - 2008. In: 5o Encontro de Economia Gaúcha. Porto Alegre - RS. Anais... Cd Roan, 2010, 30p. 
ELLIS, F. Rural livelihoods and diversity in developing countries. Oxford: 1a Ed., Oxford University Press, 273p., 2000.

FEE. Fundação Estadual de Economia e Estatística. Disponível em <www.fee.tche.br>. Acesso em setembro de 2011 .

FERREIRA, B., SILVEIRA, F. e GARCIA R. C. A agricultura familiar e o Pronaf: contexto e perspectivas. In: GARCIA GASQUES, J. e CONCEIÇÃO, J. C. (Orgs). Transformações da agricultura e politicas públicas. Brasília: IPEA, 2001.

GARCIA JR., A. R. O sul: caminho do roçado: estratégias de reprodução camponesa e transformação social. Marco Zero: São Paulo; Brasília, DF, Editora Universitária de Brasília; MCT-CNPq, 1989, 285p.

GAZOLLA, M. Agricultura familiar, segurança alimentar e políticas públicas: Uma análise a partir da produção para autoconsumo no território do Alto Uruguai/RS. Dissertação de Mestrado. Universidade Federal do Rio Grande do Sul, Porto Alegre. 2004, 287f.

GAZOLLA, M. e SCHNEIDER, S. AS DUAS "CARAS" DO PRONAF: Produtivismo ou fortalecimento da produção para autoconsumo? In: XLIII Congresso da Sociedade Brasileira de Economia e Sociologia Rural, Ribeirão Preto - SP. Anais..., CD - Roan, 2005, 21p.

GUANZIROLI, C. E. PRONAF dez anos depois: resultados e perspectivas para o desenvolvimento rural. Revista de Economia e Sociologia Rural. Rio de Janeiro, vol. 45, no 02, p. 301-328, abr/jun 2007. (Impressa em abril 2007).

IBASE. Avaliação do Proger, Proger Rural e Pronaf do Fundo de Amparo ao Trabalhador (FAT). Relatório Geral. Tomo I, junho, 1999.

IBGE. Censo Agropecuário de 1996. CD - Roan, 1996. . Censo Agropecuário de 2006. CD - Roan, 2006.

LONG, N. e PLOEG, van der J. D. Heterogeneity, actor and structure: towards a reconstitution of the concept of structure. In: BOOTH, D. (Ed.) Rethinking Social development: theory, research and practice. England, Longman, p. 62-90, 1994.

MAA. Manual Operacional do Pronaf: Programa Nacional de Fortalecimento da Agricultura Familiar. Ministério da Agricultura e Abastecimento: Secretaria de Desenvolvimento Rural. Brasília-DF, 1996, 47p.

Agricultura familiar, reforma agrária e desenvolvimento local para um novo mundo rural: politica de desenvolvimento rural com base na expansão da agricultura familiar e sua inserção no mercado. Secretaria de Desenvolvimento Rural (SDR). Brasília-DF, Versão preliminar, Março de 1999, 36p.

MDA. Brasil: Um país de todos. Balanço do Governo Lula 2003-2010. Seção da Agricultura familiar. Brasília/DF. p. $78-134,2010$.

- Ministério do Desenvolvimento Agrário. Secretaria da Agricultura Familiar (SAF). Disponível em <www.mda.gov.br>. Acesso em Maio de 2011.

MAGALHÃES, R. S. e ABRAMOVAY, R. A formação de um mercado de micro finanças no Sertão da Bahia. Revista Brasileira de Ciências Sociais. Vol. 22, n 63. 14p., fevereiro de 2007.

MATTEI, L. F. Pronaf 10 anos: mapa da produção acadêmica. Brasília, MDA, 2006, 202p. (NEAD Estudos).

- Políticas públicas de fomento á produção familiar no Brasil: o caso recente do Pronaf. In: XLV Congresso Brasileiro de Economia, Sociologia e Administração Rural. Londrina - PR. Anais... CD Roan, Julho de 2007, 20p.

MATTEI, L. F., WAQUIL, P., SCHNEIDER, S., CONTERATO, M., RADOMSKY, G., NAMIZAKY, G. e NIEDERLE, S. Uma análise dos impactos do Pronaf sobre as economias locais nas regiões Nordeste, Sudeste e Norte do Brasil. In: XLV Congresso Brasileiro de Economia, Sociologia e Administração Rural. Londrina - PR. Anais... CD - Roan, Julho de 2007, 21p.

NORTH, D. C. Economic performance through time. American Economic Review. Vol. 84, N. 3, pp. 359 - 368, Jun 1994.

PERREIRA FILHO, S. e ALVES FILHO, E. Impactos econômicos do Pronaf em Territórios Rurais: um estudo para o Médio Jequitinhonha - MG. Revista de Economia do Nordeste. V. 40, n 03, pp. 481 - 498, Julho Setembro de 2009.

PLANAF. Plano Nacional de Fortalecimento da Agricultura Familiar. Ministério da Agricultura, do Abastecimento e da Reforma Agrária. Brasília-DF, 1995, 56p.

PLANO SAFRA. Plano Safra para a agricultura familiar 2003/2004. 2003, 13p. Disponível em <http://www. pronaf.gov.br>. Acesso em 10 de fevereiro de 2004.

. Mais Alimentos: um plano da agricultura familiar para o Brasil. 2008/2009, 24p. Disponível em < http:// www.pronaf.gov.br>. Acesso em 22 de Maio de 2009.

Plano Safra da Agricultura Familiar fortalece e amplia políticas públicas. 2009/2010, 04p. Disponível em $<$ http:// www.pronaf.gov.br>. Acesso em 16 de junho de 2010 . 
. Plano Safra para a agricultura familiar 2010/2011. 12 p. Disponivel em <http://www.pronaf.gov.br>. Acesso em 22 de maio de 2011.

PLOEG, J. D. van der. El processo de trabajo agrícola y la mercantilización. In: GUZMAN, E. S. (Ed.) Ecología, Campesinato y Historia. España: Las Ediciones de La Piqueta, 1992.

PLOEG, J. D. van der, RENTING, H., BRUNORI, G., KNICKEL, K., MANNION, J., MARSDEN, T., ROEST, K., SEVILLA-GUZMÁN, E. e VENTURA, F. Rural development: From pratices and polices towards theory. Sociologia Ruralis. v. 40, nº 4, pp. 391 - 408, 2000.

TOLEDO, E. N. B. O PRONAF EM SALVADOR DAS MISSÕES: Contradições de uma política de crédito. Dissertação de Mestrado. Universidade Federal do Rio Grande do Sul, Porto Alegre. 2009, 189f.

SCHEJTMAN, A. e BERDEGUÉ, J. A. Desarollo territorial rural. Santiago: Chile, Documento de trabajo, RIMISP, 2003, 60p.

SCHNEIDER S., CAZELLA, A. A. e MATTEI, L. Histórico, caracterização e dinâmica recente do Pronaf - Programa Nacional de Fortalecimento da Agricultura Familiar. In: SCHNEIDER, S.; KUNRATH SILVA, M.;
MORUZZI MARQUES, P. E. (Orgs.). Politicas públicas e participação social no Brasil rural. Porto Alegre-RS, Editora da UFRGS, 2004, 252p., p. 21-49. (Série Estudos Rurais).

SOUZA, P. M., NEY, M. G. e PONCIANO, N. J. Comportamento da distribuição dos financiamentos do Pronaf entre as unidades da federação, no período de período de 1999 a 2009. $48^{\circ}$ Congresso da Sociedade Brasileira de Economia, Sociologia e Administração Rural. Anais... Campo Grande/MS, 17p., julho de 2010.

SOUZA, P. M., FORNAZIER, A., GOMES NEY, M. e COSTA MATA, H. T. Análise da evolução do valor dos financiamentos do Pronaf Crédito, no período de 1999 a 2010: as mudanças no número, no valor médio e na localização geográfica dos contratos. 49o Congresso da Sociedade Brasileira de Economia, Sociologia e Administração Rural. Anais... Belo Horizonte/MG, 18p., julho de 2011.

STOFFEL, J., SANTOS, P. E. e WIDZ, F. B. Programa Nacional de Fortalecimento da Agricultura Familiar (Pronaf): Uma análise do Programa na Região Sul do Brasil. 49ํㅡㄹ Congresso da Sociedade Brasileira de Economia, Sociologia e Administração Rural. Anais... Belo Horizonte/MG, 20p., julho de 2011. 
